\title{
A new male pseudohermaphrodite rat mutant with androgen deficiency
}

\author{
H. Ikadai, C. Ajisawa, S. Tsujimura, G. Watanabe*, K. Taya* and \\ T. Imamichi
}

The Imamichi Institute for Animal Reproduction, 1103 Dejimamura Fukaya, Niharigun, Ibaraki 300-01, Japan; and * Laboratory of Veterinary Physiology, Tokyo University of Agriculture and Technology, Fuchu, Tokyo 183, Japan

\begin{abstract}
Summary. A male pseudohermaphrodite rat mutant showing a blind-ending vagina, small undescended testes, rudimentary male sex accessory organs and XY karyotype was investigated. Genetic analysis revealed an autosomal single recessive transmission of this defect and indicated that the gene action is restricted to males. Microscopic examination showed an absence of typical Leydig cells in testes of the mutant. Plasma concentrations of testosterone were extremely low and the values were comparable to those of castrated male rats and did not change after castration and/or after administration of hCG. Plasma concentrations of LH and FSH were remarkably high and the values were comparable to those of long-term castrated normal male rats which declined to basal levels after administration of exogenous testosterone. Weights of thymus and adrenal glands decreased and weights of preputial glands, kidneys and male accessory sex organs increased in response to exogenous testosterone. These results indicate that the primary defect in the mutant is an androgen deficiency probably due to a Leydig cell agenesis in the testes.
\end{abstract}

Keywords: pseudohermaphrodite; mutant; rat; FSH; LH; testosterone

\section{Introduction}

Male pseudohermaphroditism is a condition in which the genital duct and/or the external genitalia are ambiguous despite the presence of testes. Sex chromosome anomaly, androgen insensitivity, disorders in androgen metabolism or synthesis and maternal ingestion of oestrogens have been reported for the aetiology (Conte \& Grumbach, 1979; Peterson \& Imperato-McGinley, 1984). Mutant animal models such as the $S x r$ mouse (Cattanach et al., 1982), Tfm rat (Bardin et al., 1970) and $T f m$ mouse (Lyon \& Hawkes, 1970) have been described, but many unsolved problems in relation to the pathogenesis of pseudohermaphroditism as well as the normal process of sexual differentiation still remain.

We have recently found a new rat mutant showing typical features male pseudohermaphroditism such as a blind-ending vagina, absent uterus or undescended testes. The rats had been maintained by sister-brother matings of the carriers in the Institute. This study describes morphological features, karyotype, hormonal findings and the mode of inheritance of the mutants.

\section{Materials and Methods}

Animals. A rat manifesting male pseudohermaphroditism was detected in 1983 by autopsy in an outbred colony of Wistar strain (Wistar Imamichi) rats that had been maintained in the Institute. The siblings were mated and successive inbreedings within litter mates of the mutant have been made for 11 generations. At least 73 pseudohermaphrodites 
have been produced in the line. Animals were maintained under conventional conditions and were fed commercial diets (EM; Oriental-kobo, Co. Ltd, Tokyo, Japan) with tap water ad libitum.

Karyotype analysis. Cultured cells of tail tissues from 3 pseudohermaphrodites were analysed by normal and G banding stains according to Yoshida (1980). In each rat, 25 metaphase cells were observed.

Morphological observation and blood collection. To examine organ weights and histology of male reproductive organs of the mutant, 6 mutant rats were decapitated at 16 weeks of age. As controls, normal male and female rats were also decapitated at the same age. Blood was collected and plasma saved at $-20^{\circ} \mathrm{C}$ for radioimmunoassay (RIA) of LH, FSH and testosterone. Groups of mutant and normal male rats were castrated at 4 weeks of age and were decapitated at 16 weeks of age. Testes, thymus, adrenal glands, preputial glands and kidneys were removed immediately after death and were weighed. Reproductive organs of pseudohermaphrodites and normal male rats were fixed in Bouin's fluid, embedded in paraffin wax, sectioned serially, and stained with haematoxylin and eosin for histological observations. Serial sections of testes of the mutants were scanned and cell types in the interstitium were examined with special care.

Pituitary contents of $\mathrm{LH}$ and FSH. Immediately after blood collection, anterior pituitary glands were removed and homogenized in $4 \mathrm{ml}$ cold $\left(4^{\circ} \mathrm{C}\right) \mathrm{NaCl}$ solution $(9 \mathrm{~g} \mathrm{NaCl} / 1)$. After centrifugation at $36000 \mathrm{~g}$ for $30 \mathrm{~min}$ at $4^{\circ} \mathrm{C}$, the supernatant fraction was obtained and stored at $-20^{\circ} \mathrm{C}$ until assayed for LH and FSH.

Responsiveness to exogenous testosterone. To examine the responsiveness of hypothalamic-pituitary axis and male accessory organs of the mutant to testosterone, 5 pseudohermaphrodite rats were injected s.c. with $0.5 \mathrm{mg}$ testosterone propionate (Tokyo Kasei, Tokyo, Japan) dissolved in $0.1 \mathrm{ml}$ sesame oil daily for 10 weeks from 6 weeks of age. As control groups, normal male rats castrated at 4 weeks of age and intact female rats were treated with testosterone propionate in the same manner. All animals were decapitated at 16 weeks of age. Blood was collected and plasma saved for RIAs of LH and FSH. The thymus, adrenal glands, preputial glands and kidneys were removed and weighed immediately after death. The epididymides were also removed, fixed in Bouin's fluid and prepared for histological examination.

Testicular responsiveness to human chorionic gonadotrophin ( $h C G$ ). Pseudohermaphrodite $(\mathrm{N}=5)$ and normal male $(\mathrm{N}=5$ ) rats were treated i.v. with 10 i.u. hCG (Dennka Seiyaku Co. Ltd, Kawasaki, Japan) dissolved in 0.1 $\mathrm{ml}$ $0.85 \%(\mathrm{w} / \mathrm{v}) \mathrm{NaCl}$ solution at $09: 00 \mathrm{~h}$ at 16 weeks of age. Animals were decapitated $3 \mathrm{~h}$ after the treatment and blood plasma was saved for RIA of testosterone.

Genetic analysis. Since the mutant was sterile, the sires and dams producing the mutant, designated as carriers, were used for genetic analyses. Carriers in the line were outcrossed with the IS line, kindly offered by Dr M. Ishibashi (Azabu University, Kanagawa, Japan). The incidence of mutants, defined by small undescended testes in the body cavity, was observed in the F1, F2 and backcross generations. In the F2 and backcross generations, litters produced by carrier F1 males and females were used for statistical analysis.

Hormone assays. Plasma testosterone concentrations were measured by a double-antibody RIA using ${ }^{125}$ Ilabelled radioligands as described by Taya et al. (1985). Antiserum against testosterone (GDN 250; Gay \& Kerlen, 1978) was provided by Dr G. D. Niswender (Colorado State University, Fort Collins, CO, U.S.A.); the sensitivity of the assay was $0.625 \mathrm{pg} /$ tube and the intra- and interassay coefficients of variation were 8.0 and $14 \cdot 2 \%$ respectively.

Plasma LH and FSH concentrations were measured using the NIADDK RIA kits for rat LH and FSH. Iodinated preparations were rat LH-I-5 and FSH-I-5. The antisera used were anti-rat LH-S-8 and anti-rat FSH-S-11. Results were expressed in terms of NIADDK rat LH-RP-1 and FSH-RP-1. The assay sensitivities were $0 \cdot 25 \mathrm{ng} \mathrm{LH} / \mathrm{tube}$ and $1.2 \mathrm{ng} \mathrm{FSH} /$ tube and the intra- and interassay coefficients of variation were 7.0 and $23.0 \%$ for $\mathrm{LH}$ and 4.5 and $7.5 \%$ for FSH respectively.

Statistics. Student's $t$-test was used for statistical comparison between means and $\chi^{2}$ tests were used for genetic analysis. A value of $P<0.05$ was considered to be significant.

\section{Results}

\section{Macroscopic observations (Fig. 1)}

The pseudohermaphrodite rats were indistinguishable in appearance from normal females. They did not have the scrotum, but had the vagina ending in a blind cul-de-sac. The nipples appeared similar to those of normal female rats. Vaginal perforatior. of the mutant rats was 
observed at 6-7 weeks of age, although the vagina usually opens at about 5 weeks of age in normal female rats of this strain. Therefore, the pseudohermaphrodite rats can be distinguished from normal female rats without dissection by the delayed vaginal openings.

Internally, there were small undescended testes just below the kidneys in the body cavity. The testes were surrounded by body fat, pale in colour and small in size. Rudimentary male sex accessory organs, epididymis and vas deferens could be seen in some but not all mutant rats.

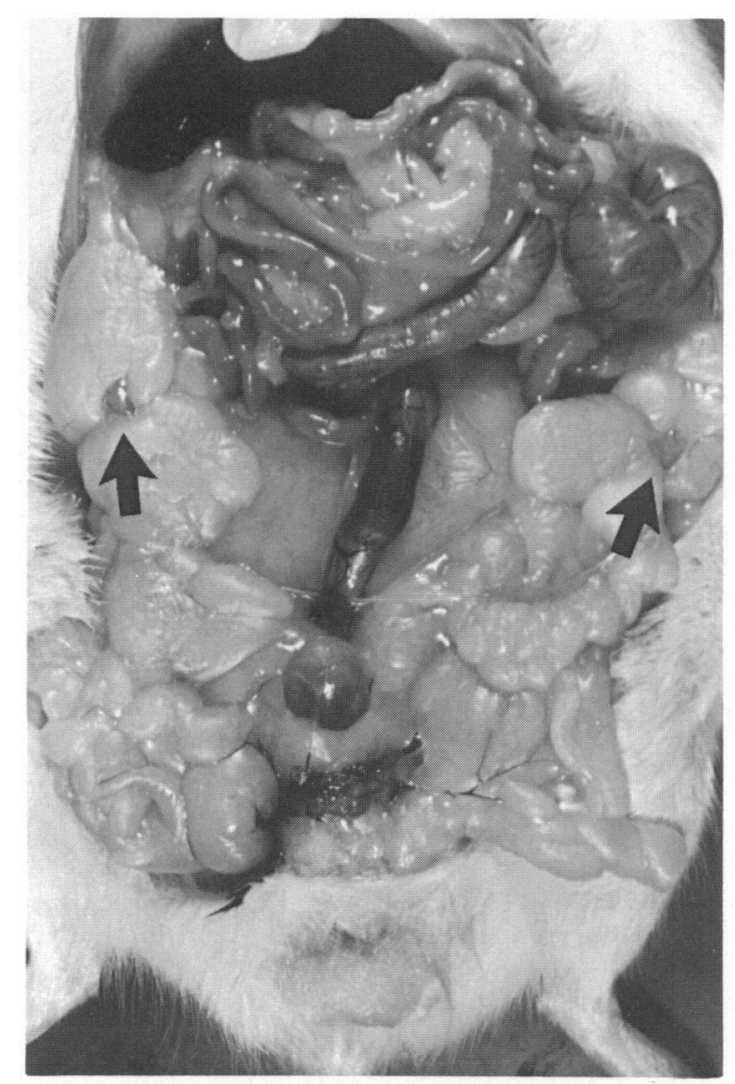

Fig. 1. Body cavity of the pseudohermaphrodite rat mutant. Small undescended testes surrounded by body fat were found just below the kidneys (arrows).

\section{Body and organ weights (Table 1)}

The average body weight of the mutant rats was intermediate between those of normal male and female rats of the same age. The thymus weight was significantly greater in the mutant rats than in normal male and female rats. The average weights of preputial glands and kidneys were significantly less in the mutant rats than in normal male rats. The average weight of testes in the mutant rats was about $5 \%$ that of normal male rats.

Histology of the testis and rudimentary accessory organs (Figs 2 \& 4)

In testes of the mutant, no spermatogenesis existed; the seminiferous tubules contained only a few gonocytes, early spermatocytes and degenerated Sertoli cells. In the interstitial tissue, fibroblasts with an elongated nucleus were prominent. Typical Leydig cells and macrophages with a 
Table 1. Body and organ weights in pseudohermaphrodite, male and female rats

\begin{tabular}{|c|c|c|c|c|c|c|c|}
\hline Treatment & $\begin{array}{c}\text { No. of } \\
\text { animals }\end{array}$ & $\begin{array}{l}\text { Body } \\
\text { weight } \\
\text { (g) }\end{array}$ & $\begin{array}{l}\text { Thymus } \\
\text { (mg) }\end{array}$ & $\begin{array}{l}\text { Adrenal } \\
\text { glands } \\
\text { (mg) }\end{array}$ & $\begin{array}{l}\text { Preputial } \\
\text { glands } \\
\text { (mg) }\end{array}$ & $\begin{array}{l}\text { Kidneys } \\
\text { (mg) }\end{array}$ & $\begin{array}{l}\text { Testes } \\
\text { (mg) }\end{array}$ \\
\hline \multicolumn{8}{|c|}{ Pseudohermaphrodite } \\
\hline Intact & 6 & $\begin{array}{c}397.0 \pm \\
7.6\end{array}$ & $\frac{760 \cdot 3 \pm}{67 \cdot 2} \pm$ & $\underset{7 \cdot 6}{90 \cdot 3 \pm}$ & $\begin{array}{l}82.2 \pm \\
10.7\end{array}$ & $\begin{array}{c}2476.0 \pm \\
194.0\end{array}$ & $\begin{array}{r}136 \cdot 5 \pm \\
17 \cdot 1\end{array}$ \\
\hline Castrated & 5 & $\underset{7 \cdot 2}{415 \cdot 2 \pm}$ & $\frac{684 \cdot 4}{49 \cdot 8} \pm$ & $\begin{array}{c}82 \cdot 4 \pm \\
3 \cdot 5\end{array}$ & $\begin{array}{c}93.0 \pm \\
6.3\end{array}$ & $\begin{array}{c}2470 \cdot 0 \pm \\
75 \cdot 2\end{array}$ & - \\
\hline$+\mathrm{TP}^{*}$ & 5 & $\begin{array}{c}393.4 \pm \\
8.9\end{array}$ & $\begin{array}{c}198 \cdot 6 \pm \\
12 \cdot 6^{\mathrm{a}}\end{array}$ & $\begin{array}{c}53 \cdot 4 \pm \\
2 \cdot 4^{\mathrm{a}}\end{array}$ & $\begin{array}{c}345 \cdot 4 \pm \\
17 \cdot 9^{\mathrm{a}}\end{array}$ & $\begin{array}{c}3132 \cdot 0 \pm \\
162 \cdot 0^{\mathrm{a}}\end{array}$ & $\begin{array}{c}116 \cdot 4 \pm \\
5 \cdot 5\end{array}$ \\
\hline \multicolumn{8}{|l|}{ Male } \\
\hline Intact & 6 & $\begin{array}{r}500 \cdot 0 \pm \\
13 \cdot 0^{\mathrm{a}}\end{array}$ & $\begin{array}{l}423 \cdot 7 \pm \\
26 \cdot 7^{\mathrm{a}}\end{array}$ & $\frac{66 \cdot 2 \pm}{4 \cdot 1^{\mathrm{a}}}$ & $\begin{array}{r}249 \cdot 0 \pm \\
8 \cdot 1^{\mathrm{a}}\end{array}$ & $\begin{array}{c}3836 \cdot 3 \pm \\
89 \cdot 7^{\mathrm{a}}\end{array}$ & $\begin{array}{c}2890 \cdot 8 \pm \\
92 \cdot 0^{\mathrm{a}}\end{array}$ \\
\hline Castrated & 6 & $\begin{array}{c}402 \cdot 2 \pm \\
12 \cdot 9^{\mathrm{b}}\end{array}$ & $\begin{array}{c}1072 \cdot 7 \pm \\
94 \cdot 8^{\mathrm{b}}\end{array}$ & $\begin{array}{l}85 \cdot 5 \pm \\
2 \cdot 7^{\mathrm{b}}\end{array}$ & $\begin{array}{r}108 \cdot 7 \pm \\
2 \cdot 0^{\mathrm{b}}\end{array}$ & $\begin{array}{c}2509 \cdot 2 \pm \\
88 \cdot 7^{\mathrm{b}}\end{array}$ & - \\
\hline Castrated $+\mathrm{TP}^{*}$ & 5 & $\begin{array}{c}433 \cdot 0 \pm \\
12 \cdot 8^{\mathrm{b}}\end{array}$ & $\begin{array}{c}275 \cdot 8 \pm \\
15 \cdot 4^{\mathrm{b}}\end{array}$ & $\underset{4 \cdot 7}{63 \cdot 8 \pm}$ & $\begin{array}{c}285 \cdot 4 \pm \\
5 \cdot 7^{\mathrm{b}}\end{array}$ & $\begin{array}{c}4033 \cdot 0 \pm \\
108 \cdot 5\end{array}$ & - \\
\hline \multicolumn{8}{|l|}{ Female } \\
\hline Intact & 6 & $\begin{array}{r}271 \cdot 7 \pm \\
10 \cdot 2^{\mathrm{a}}\end{array}$ & $\begin{array}{l}384 \cdot 8 \pm \\
26 \cdot 0^{\mathrm{a}}\end{array}$ & $\begin{array}{c}82 \cdot 2 \pm \\
6 \cdot 2\end{array}$ & $\begin{array}{c}91 \cdot 7 \pm \\
8 \cdot 8\end{array}$ & $\begin{array}{c}2188.0 \pm \\
161 \cdot 5\end{array}$ & - \\
\hline$+\mathrm{TP}^{*}$ & 6 & $\begin{array}{r}322 \cdot 8 \pm \\
13 \cdot 6^{\mathrm{c}}\end{array}$ & $\begin{array}{c}202 \cdot 5 \pm \\
16 \cdot 1^{\mathrm{c}}\end{array}$ & $\begin{array}{c}62 \cdot 2 \pm \\
3 \cdot 1^{c}\end{array}$ & $\begin{array}{r}345 \cdot 7 \pm \\
20 \cdot 7^{c}\end{array}$ & $\begin{array}{c}3097 \cdot 0 \pm \\
153 \cdot 7^{\mathrm{c}}\end{array}$ & - \\
\hline
\end{tabular}

Values are means \pm s.e.m.

*Animals were treated s.c. with $0.5 \mathrm{mg}$ testosterone propionate dissolved in $0.1 \mathrm{ml}$ sesame oil daily for 10 weeks from 6 weeks of age.

a, $P<0.05$ compared with intact pseudohermaphrodite.

b, $P<0.05$ compared with the value of the intact male rat.

c, $P<0.05$ compared with the value of the intact female rat.

relatively large round nucleus with heterochromatin were not seen whereas large eosinophilic cells that were thought to be mast cells were present (Fig. 2d). The rudimentary epididymis and vas deferens observed macroscopically in some rats showed undeveloped tubular structures (Fig. 4a).

\section{Plasma concentrations of testosterone, LH and FSH (Table 2)}

In the pseudohermaphrodite rat, plasma concentrations of testosterone were significantly lower than those of normal male and female rats, whereas plasma concentrations of LH and FSH were significantly higher in the mutant rats than in normal male rats. Plasma concentrations of testosterone, LH and FSH in the mutant rats did not change after castration whereas in the normal male plasma concentrations of testosterone decreased significantly and there was a concomitant increase in plasma concentrations of LH and FSH. Plasma concentrations of testosterone, LH and FSH in the mutant rats were comparable to those seen in long-term castrated male rats.

\section{Pituitary contents of LH and FSH (Table 3)}

Pituitary contents of $\mathrm{LH}$ in the mutant rats were significantly higher than in normal male rats while FSH contents were not different between the two groups. Pituitary contents of LH but not FSH in the mutant rats increased significantly after castration whereas both LH and FSH contents increased significantly in normal male rats after surgery.

\section{Responsiveness to testosterone}

In the testosterone-treated mutant rat, development of the male reproductive accessory organs, including epididymis, vas deferens, seminal vesicle and prostate gland, was observed (Fig. 4b). 

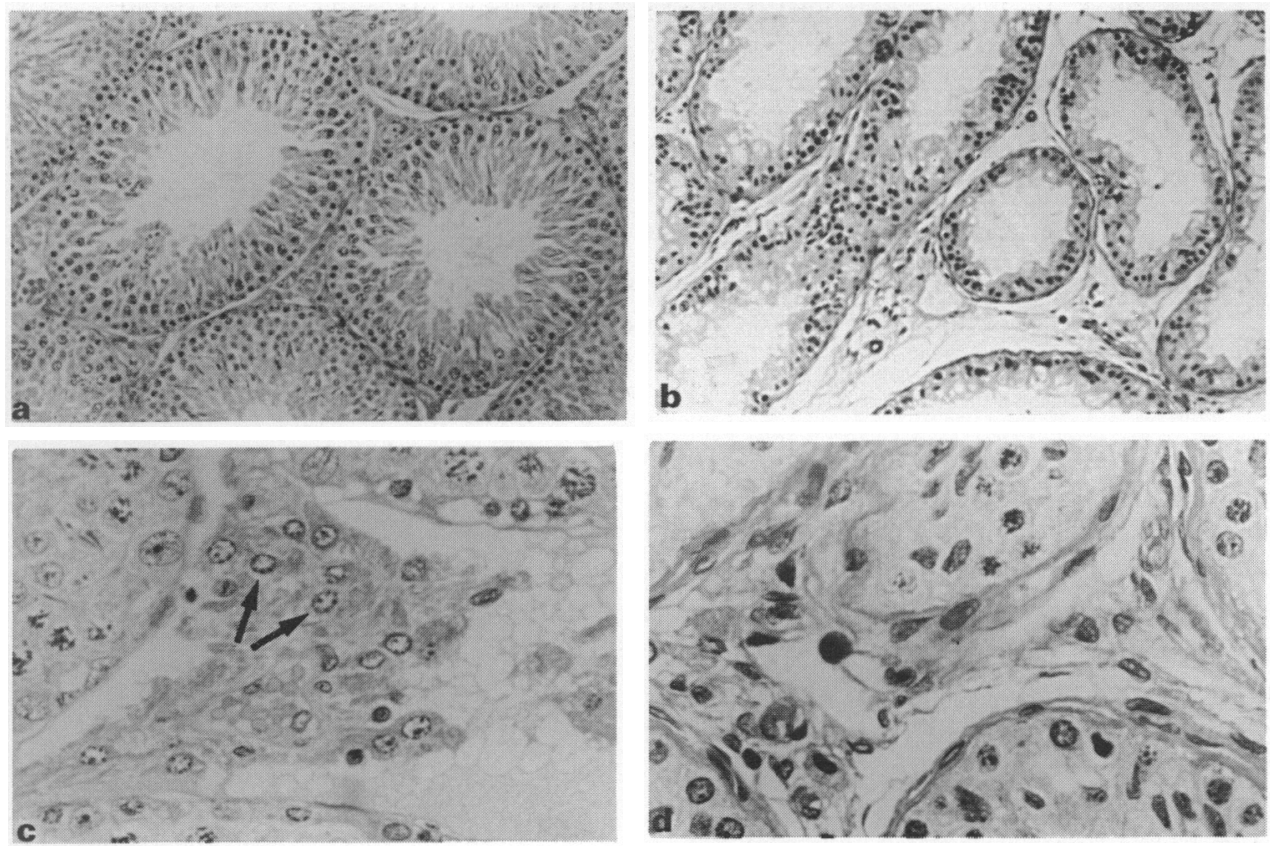

Fig. 2. Histological sections of testes from normal rat (a and c) and pseudohermaphrodite rat mutant ( $b$ and d). In testes of the mutant, seminiferous tubules including a few Sertoli cells and gonocytes were seen but no spermatogenesis had occurred (b). In the interstitial tissue, fibroblast-like cells with an elongated nucleus were prominent but typical Leydig cells with a round nucleus showing heterochromatin as shown in the control (c, arrows) were not seen in the mutant rat (d). a and $b \times 139, \mathrm{c}$ and $\mathrm{d} \times 556$.

However, the degree of development of these accessory organs was different in individual animals or between each side of the same animals. In the example shown in Fig. 3, the caput and cauda epididymidis, vas deferens, seminal vesicle on the left side and the vas deferens and seminal vesicle on the right side developed in response to exogenous testosterone. In another animal, the seminal vesicle on the left side and ventral prostate on both sides developed in response to testosterone (data not shown). Histological observation of the developed accessory organs revealed tubular and glandular structures and secretory products characteristic of these organs (Fig. 4b). There was no significant change in weight and histology of testes in the testosterone-treated mutant rat. In the testosterone-treated mutant rat, the weights of thymus and adrenal glands were significantly smaller but the weights of preputial glands and kidneys were significantly larger than those of the untreated mutant rat (Table 1). Plasma concentrations of LH and FSH were significantly lower in the testosterone-treated mutants than in the untreated mutant rats. Values were below the levels of those in normal male rats (Table 2). After administration of testosterone, pituitary contents of $\mathbf{L H}$ decreased significantly in mutants and castrated males as compared with untreated animals in each group. It was also true for FSH (Table 3).

\section{Testicular responsiveness to $h C G$}

At $3 \mathrm{~h}$ after the injection of hCG into the mutant rat, plasma concentrations of testosterone did not change compared with those of untreated mutant rat, whereas a marked increase was noted in normal male rats in response to hCG (Table 2). 


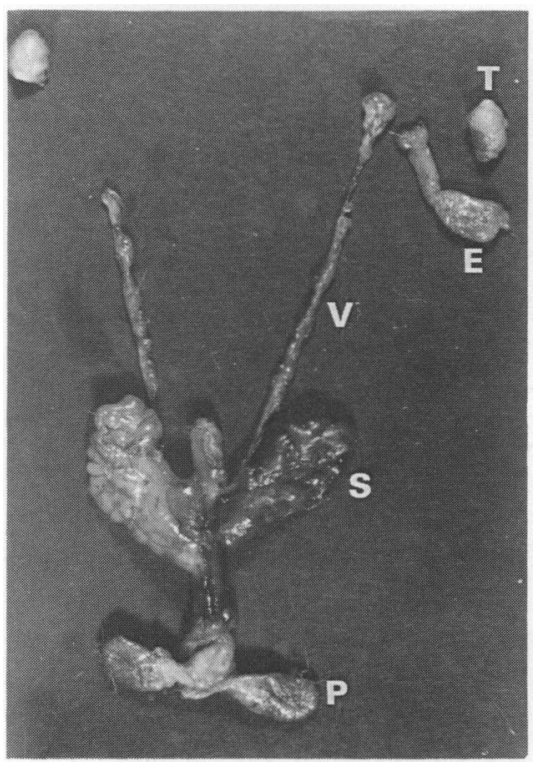

Fig. 3

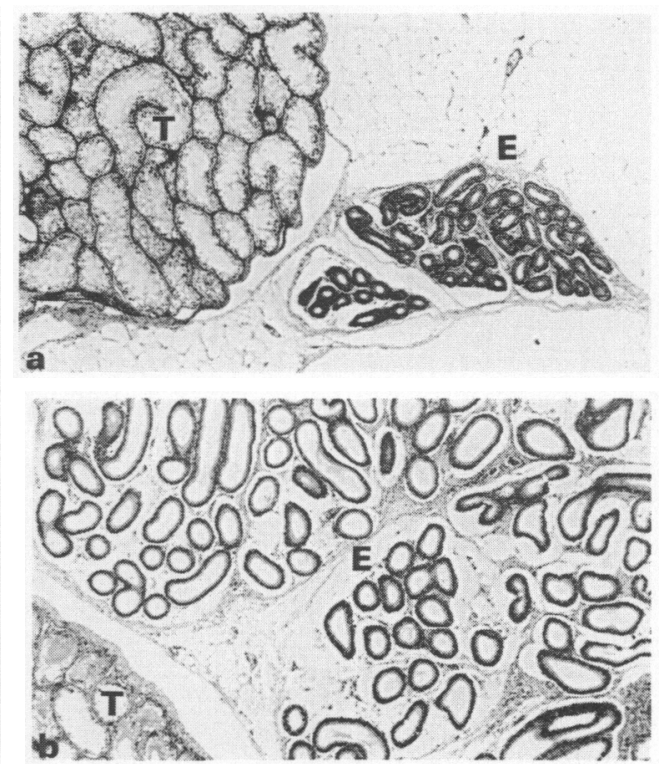

Fig. 4

Fig. 3. The whole ejaculatory duct with the accessory glands of a testosterone-treated mutant. The epididymis $(\mathrm{E})$, vas deferens $(\mathrm{V})$, and seminal vesicle $(\mathrm{S})$ on the right side, and the vas deferens and seminal vesicle on the left side had developed in this rat. T, testis; $\mathrm{P}$, preputial gland.

Fig. 4. Rudimentary male sex accessory organs seen in intact (a) and testosterone-treated (b) pseudohermaphrodite rats. T, testis; E, epididymis. $\times 20$.

Table 2. Plasma concentrations of testosterone, LH and FSH in pseudohermaphrodite, male and female rats

\begin{tabular}{|c|c|c|c|c|}
\hline Treatment & $\begin{array}{l}\text { No. of } \\
\text { animals }\end{array}$ & $\begin{array}{l}\text { Testosterone } \\
(\mathrm{ng} / \mathrm{ml})\end{array}$ & $\underset{(\mathrm{ng} / \mathrm{ml})}{\mathrm{LH}}$ & $\begin{array}{l}\text { FSH } \\
(\mathrm{ng} / \mathrm{ml})\end{array}$ \\
\hline \multicolumn{5}{|c|}{ Pseudohermaphrodite } \\
\hline Intact & 6 & $0.11 \pm 0.02$ & $986.9 \pm 116.5$ & $1548 \cdot 7 \pm 101 \cdot 4$ \\
\hline Castrated & 5 & $0.12 \pm 0.01$ & $630 \cdot 8 \pm 21 \cdot 5$ & $1445.4 \pm \quad 38.2$ \\
\hline$+\mathrm{TP}^{*}$ & 5 & 二 & $31.7 \pm 3.6^{\mathrm{a}}$ & $430 \cdot 1 \pm 23 \cdot 8^{\mathrm{a}}$ \\
\hline $\mathrm{hCG}^{\dagger}$ & 5 & $0.07 \pm 0.02$ & 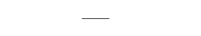 & - \\
\hline \multicolumn{5}{|l|}{ Male } \\
\hline Intact & 6 & $4 \cdot 24 \pm 0 \cdot 69^{\mathrm{a}}$ & $107 \cdot 3 \pm 19 \cdot 7^{\mathrm{a}}$ & $626.5 \pm 45 \cdot 8^{\mathrm{a}}$ \\
\hline Castrated & 6 & $0.06 \pm 0.03^{b}$ & $503 \cdot 5 \pm 46 \cdot l^{b}$ & $1452.7 \pm 82.9^{\mathrm{b}}$ \\
\hline Castrated + TP* & 5 & 二 & $27.6 \pm \quad 3 \cdot 3^{\mathrm{b}}$ & $409 \cdot 0 \pm 21 \cdot 2^{b}$ \\
\hline $\mathrm{hCG}^{\dagger}$ & 5 & $19.64 \pm 1.27^{b}$ & - & - \\
\hline \multicolumn{5}{|l|}{ Female } \\
\hline Intact & 6 & $0 \cdot 32 \pm 0.08^{\mathrm{a}}$ & - & - \\
\hline
\end{tabular}

Values are means \pm s.e.m.

*Animals were treated s.c. with $0.5 \mathrm{mg}$ testosterone propionate dissolved in $0.1 \mathrm{ml}$ sesame oil daily for 10 weeks from 6 weeks of age.

†Animals were treated i.v. with $10 \mathrm{i} . \mathrm{u}$. hCG dissolved in $0.1 \mathrm{ml} 0.85 \% \mathrm{NaCl}$ at $09: 00 \mathrm{~h}$ at 16 weeks of age and they were decapitated $3 \mathrm{~h}$ after the treatment.

a, $P<0.05$ compared with intact pseudohermaphrodite.

b, $P<0.05$ compared with the value of the intact male rat. 
Table 3. Pituitary contents of LH and FSH in pseudohermaphrodite and male rats

\begin{tabular}{lccc}
\hline Treatment & $\begin{array}{c}\text { No. of } \\
\text { animals }\end{array}$ & $\begin{array}{c}\text { LH } \\
(\mu \mathrm{g} / \text { pituitary })\end{array}$ & $\begin{array}{c}\text { FSH } \\
(\mu \mathrm{g} / \text { pituitary })\end{array}$ \\
\hline Pseudohermaphrodite & & & \\
$\quad$ Intact & 6 & $652 \cdot 5 \pm 36 \cdot 9$ & $547 \cdot 7 \pm 31 \cdot 0$ \\
$\quad$ Castrated & 5 & $889 \cdot 3 \pm 66 \cdot 6^{\mathrm{a}}$ & $595 \cdot 8 \pm 39 \cdot 3$ \\
$\quad$ TP* & 5 & $165 \cdot 7 \pm 20 \cdot 4^{\mathrm{a}}$ & $301 \cdot 7 \pm 13 \cdot 7^{\mathrm{a}}$ \\
Male & & & \\
$\quad$ Intact & 6 & $186 \cdot 1 \pm 27 \cdot 9^{\mathrm{a}}$ & $515 \cdot 6 \pm 53 \cdot 4$ \\
$\quad$ Castrated & 6 & $842 \cdot 0 \pm 26 \cdot 8^{\mathrm{b}}$ & $786 \cdot 8 \pm 15 \cdot 3^{\mathrm{b}}$ \\
$\quad$ Castrated + TP* & 5 & $33 \cdot 9 \pm 6 \cdot 4^{\mathrm{b}}$ & $301 \cdot 6 \pm 12 \cdot 3^{\mathrm{b}}$ \\
\hline
\end{tabular}

Values are means \pm s.e.m.

*Animals were treated s.c. with $0.5 \mathrm{mg}$ testosterone propionate dissolved in $0 \cdot 1 \mathrm{ml}$ sesame oil daily for 10 weeks from 6 weeks of age.

a, $P<0.05$ compared with intact pseudohermaphrodite.

b, $P<0.05$ compared with the value of the intact male rat.

\section{Karyotypes}

The mutant rats were cytogenetically males that had a normal karyotype with 40 autosomes, and an $\mathrm{X}$ and a $\mathrm{Y}$ chromosome (Fig. 5). Sex chromosome anomaly was not observed in this mutant.

\section{Genetic analysis (Table 4)}

Since the pseudohermaphrodite rats were sterile, the line producing the mutant has been maintained by matings of the phenotypically normal litter-mates. Out of 109 litters obtained from these matings, the mutant rats were observed in 41 litters $(219$ females, 125 males and 73 pseudohermaphrodite offspring). The ratio of females to phenotypic males plus mutants was about 1 to 1 , supporting the finding obtained from karyotype analyses that the mutant is a cytogenetically normal male. The incidence of the mutant in the males karyotyped was $36.8 \%$. This value is intermediate between theoretical values for recessive homozygotes in offspring from matings of heterozygotes with heterozygotes $(25 \%)$ and in offspring from matings of heterozygotes with recessive homozygotes $(50 \%)$ for an autosomal recessive trait. The incidence of the mutant in the line therefore fits the hypothesis that the pseudohermaphroditism is controlled by an autosomal single recessive gene the action of which is limited to males. In this case, the pseudohermaphrodite rats are recessive homozygotes; phenotypically normal carrier males are heterozygotes and carrier females include heterozygotes and recessive homozygotes.

To obtain additional evidence for this hypothesis, carrier males and females in the line were reciprocally outcrossed with an unrelated line. In the Fl generations derived from carrier males and females (crosses 1 and 4 in Table 4), the mutant did not appear. This finding fits the hypothesis described above, in which Fl animals include dominant homozygotes and heterozygotes. Therefore, the incidence of the mutant in the $\mathrm{F} 2$ and backcross generations was analysed in offspring from matings of proven $\mathrm{F} 1$ carrier females with proven $\mathrm{F} 1$ carrier males, and proven carriers males in the line with proven F1 carrier females, respectively. The incidence of the mutant in the F2 (crosses 2 and 5 in Table 4) and backcross (crosses 3 and 6 in Table 4) generations was consistent with the expected value for autosomal single recessive transmission.

\section{Discussion}

Endocrine studies as well as histological examinations clearly demonstrate that male pseudohermaphroditism in this rat mutant results from an absence of androgen secretion by testes. The 


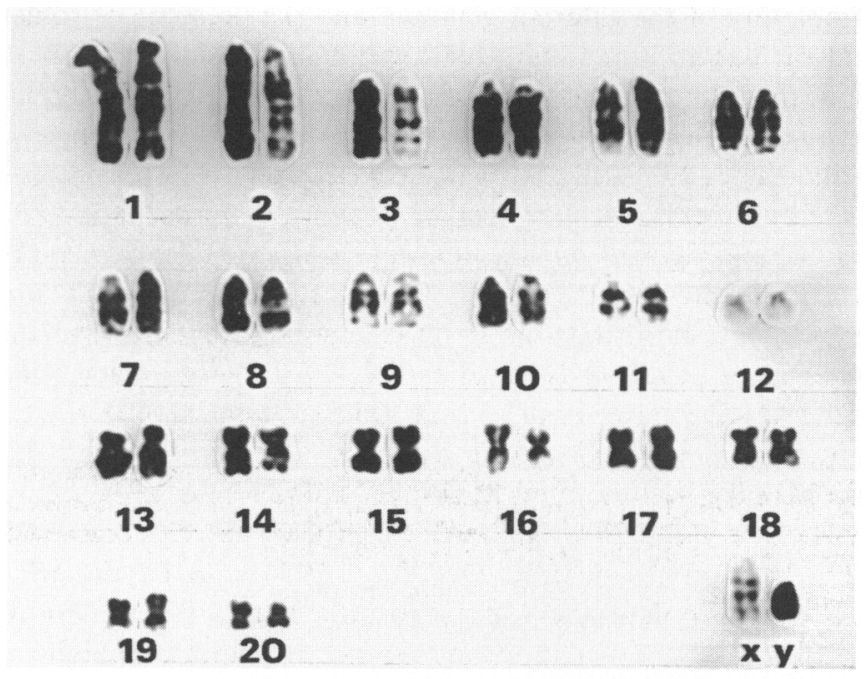

Fig. 5. G-band staining of chromosomes of the mutant. The mutants have a normal XY karyotype.

Table 4. Segregation of pseudohermaphrodite (Pseudo.) rats in offspring from crosses with the unrelated (IS) line

\begin{tabular}{|c|c|c|c|c|c|c|c|c|}
\hline \multirow[b]{2}{*}{ Cross } & \multicolumn{4}{|c|}{ Observed } & \multicolumn{4}{|c|}{$\begin{array}{l}\text { Expected values } \\
\text { for single recessive }\end{array}$} \\
\hline & Female & Pseudo. & Male & $(\%)$ & Pseudo. & Male & $(\%)$ & $\chi^{2}$ \\
\hline 1. Carrier* males $\times$ IS females & 25 & 0 & 27 & (0) & 0 & 27 & (0) & 0 \\
\hline 2. Carrier F1 males $\times$ carrier FI females & 84 & 19 & 62 & $(23 \cdot 5)$ & $20 \cdot 25$ & $60 \cdot 75$ & $(25 \cdot 0)$ & $0 \cdot 103$ \\
\hline 3. Carrier males $\times$ carrier F1 females & 60 & 16 & 43 & $(27 \cdot 1)$ & $14 \cdot 75$ & $44 \cdot 25$ & $(25 \cdot 0)$ & $0 \cdot 141$ \\
\hline 4. IS males $\times$ carrier females & 38 & 0 & 38 & $(0)$ & 0 & 38 & $(0)$ & 0 \\
\hline 5. Carrier Fl males $\times$ carrier FI females & 136 & 31 & 102 & $(23 \cdot 3)$ & $33 \cdot 25$ & $99 \cdot 75$ & $(25 \cdot 0)$ & 0.203 \\
\hline 6. Carrier males $\times$ carrier F1 females & 46 & 11 & 35 & $(23.9)$ & $11 \cdot 5$ & $34 \cdot 5$ & $(25 \cdot 0)$ & 0.029 \\
\hline
\end{tabular}

*Carrier denotes animals carrying the gene which produces pseudohermaphrodites.

Number in parentheses indicates percentage of pseudohermaphrodites.

testes of the mutant are not only small in size with pseudohermaphroditism but also showed an absence of the Leydig cells which correlated with extremely low concentrations of testosterone and elevated concentrations of LH and FSH in the plasma. The present results demonstrated that the small amount of testosterone present in the plasma was from the adrenal glands, and not of testicular origin since it did not change after castration or after hCG administration. Additional evidence for androgen deficiency in the testes was obtained from the organ weights. Weights of androgen-sensitive end organs such as the thymus, adrenal glands, preputial glands and kidneys of the mutant rat were comparable to those of castrated male rats and did not change after castration. However, these organs of the mutant rat are androgen-sensitive since they responded to exogenous testosterone. Histological examination of the testes showed that failure to secrete testosterone was due to an absence of Leydig cells. Some differentiated and functioning Leydig cells, however, must have been present in the fetal stages of the mutant rat at a critical period of sexual differentiation, as 
indicated by the ambiguity of the external genitalia and the presence of some male accessory sex organs. The mutant rat has an unmasculinized hypothalamus since implantation of ovary under the kidney capsule of the adult mutant rat produced a cyclic pattern of vaginal smear (K. Tauchi, unpublished observation). These results clearly indicate that androgen deficiency already existed in the mutant rat during the early post-natal period since roles for testosterone in the expression of masculine patterns of hypothalamus have been demonstrated in this period (Pfeiffer, 1936).

The pathogenesis of androgen deficiency in testes cannot be fully clarified by the present study. Male pseudohermaphroditism with androgen deficiency in testes can result from a defect of steroid biosynthetic enzymes (Conte \& Grumbach, 1979; Peterson \& Imperato-McGinley, 1984), gonadotrophic unresponsiveness of Leydig cells (Bardin et al., 1973; Perez-Palacios et al., 1981, 1984), and hypoplasia (Brown et al., 1978; Lee et al., 1982), agenesis (Berthezene et al., 1976) or abnormal differentiation (Schwartz et al., 1981) of Leydig cells. Defects of steroid biosynthetic enzymes are probably unlikely, since lipid adrenal hyperplasia which is usually seen in defects of 20-22desmolase, $17 \alpha$-hydroxysteroid dehydrogenase, and $\Delta^{5}-3 \beta$-hydroxysteroid dehydrogenase (Conte \& Grumbach, 1979; Peterson \& Imperato-McGinley, 1984) and Leydig cell hyperplasia usually seen in defects of 17-20-desmolase and 17 $\beta$-hydroxysteroid dehydrogenase (Goebelsmann et al., 1973; Forest et al., 1980) were not seen in the mutant rat. In spite of the high concentrations of LH, no typical Leydig cells were seen in serial sections of testes in the mutant rat. Gonadotrophin unresponsiveness, agenesis or abnormal differentiation of Leydig cells may be responsible for the aetiology of pseudohermaphroditism in the mutant rat. The administration of exogenous testosterone resulted in a significant decrease in the pituitary and plasma concentrations of LH and FSH in all mutant rats, indicating that the mutant rat has functional integrity of the hypothalamicpituitary unit in terms of an androgen-induced negative-feedback mechanism. In addition, the epididymis and vas deferens developed in response to exogenous testosterone. These results indicated that defective testicular androgen synthesis rather than a defective mechanism of action of androgen at target organs accounts for the origin of male pseudohermaphroditism in this mutant rat. An absence of Leydig cells has been reported to be the cause of male pseudohermaphroditism in humans (Berthezene et al., 1976; Brown et al., 1978; Lee et al.1982). However, another explanation would be that receptors for LH were missing from the Leydig cells, and so these cells were unable to develop and secrete androgens. No receptor studies for LH have been carried out on the testicular tissue of these mutants. Also, it is not clear in the present study whether a defect of steroid production also exists in adrenal glands as well as testes of the mutant rats.

Genetic analysis demonstrated an autosomal single recessive transmission of the defect. It is clear from the phenotype and mode of inheritance that the gene responsible for the defect is different from previously described genes such as $T f m, H y a, T d y, S x r$, Tas and $T d a$ which cause abnormal sex differentiation. The X-linked $T f m$ gene controls the androgen receptor of end organs (Lyon \& Hawkes, 1970; Bardin et al., 1973; Stanley et al., 1973). The Y-linked Hya (Wachtel et al., 1975) and $T d y$ (Eicher et al., 1982), autosomal dominant Sxr (Cattanach et al., 1971) and Tas (Washburn \& Eicher, 1983), and autosomal recessive Tda (Eicher \& Washburn, 1983) genes concern primary sex determination. We propose to designate the gene as $M p$ representing male pseudohermaphrodite. The action of the $M p$ gene is limited to males and female homozygotes are phenotypically normal and fertile. This suggests that the $M p$ gene is responsible for androgen deficiency in testes but it may not affect ovarian steroidogenesis. Therefore, this mutant will be useful for studies of genetic mechanisms which control steroidogenesis or differentiation of Leydig cells.

We thank Dr A. F. Parlow and the Rat Pituitary Hormone Distribution Program, NIADDK, NIH, Bethesda, MD, U.S.A., for providing RIA materials; Dr G. D. Niswender, Department of Physiology and Biophysics, Colorado State University, Fort Collins, CO, U.S.A., for antiserum to testosterone (GDN 250); Teikoku Hormone MFG Co., Ltd, Tokyo, Japan, for providing testosterone; and Dr Y. Wada for valuable advice on karyotype analysis. 


\section{References}

Bardin, C.W., Bullock, L., Schneider, G., Allison, J.E. \& Stanley, A.J. (1970) Pseudohermaphrodite rat: end organ insensitivity to testosterone. Science, N.Y. 167, $1136-1137$.

Bardin, C.W., Bullock, L.P., Sherins, R.J., Mowszowicz, I. \& Blackburn, W.R. (1973) Androgen metabolism and mechanism of action in male pseudohermaphroditism: a study of testicular feminization. Recent Prog. Horm. Res. 29, 65-109.

Berthezene, F., Forest, M., Grimaud, J.A., Claustrat, B. \& Mornex, R. (1976) Leydig cell agenesis, a cause of male pseudohermaphroditism. New Engl. J. Med. 295, 969-972.

Brown, D.M., Markland, C. \& Dehner, L.P. (1978) Leydig cell hypoplasia: a cause of male pseudohermaphroditism. J. clin. Endocr. Metab. 46, 1-7.

Cattanach, B.M., Pollard, C.E. \& Hawkins, S.G. (1971) Sex-reversal mice: $\mathrm{XX}$ and $\mathrm{XO}$ males. Cytogenetics 10, 318-337.

Cattanach, B.M., Evans, E.P., Burtenshaw, M.D. \& Barlow, J. (1982) Male, female and intersex development in mice of identical chromosomal constitution. Nature, Lond. 300, 445-446.

Conte, F.A. \& Grumbach, M.M. (1979) Pathogenesis, classification, diagnosis and treatment of anomalies of sex. In Endocrinology, pp. 1317-1351. Eds L. J. DeGroot, G. F. Cahill, W. D. Odell, L. Martini, J. T. Potts, D. H. Nelson, E. Steinberger \& A. I. Winegrad. Grune \& Stratton, New York.

Eicher, E. \& Washburn, L.L. (1983) Inherited sex reversal in mice: identification of a new primary sex determining gene. J. exp. Zool. 228, 297-304.

Eicher, E., Washburn, L.L., Whitney, J.B. \& Morrow, K.E. (1982) Mus poschiavinus Y chromosome in the $\mathrm{C} 57 \mathrm{BL} / 6 \mathrm{~J}$ murine genome causes sex reversal. Science, N.Y. 217, 535-537.

Forest, M.G., Lecornu, M. \& de Peretti, E. (1980) Familial male pseudohermaphroditism due to 17-20desmolase deficiency. I. In vitro endocrine studies. $J$. clin. Endocr. Metab. 50, 826-833.

Gay, V.L. \& Kerlen, J.T. (1978) Serum LH and FSH following passive immunization against circulating testosterone in the intact male rat and in orchidectomized rats bearing subcutaneous silastic implants of testosterone. Archs Androl. 1, 257-266.

Goebelsmann, U., Horton, R., Mestman, J.H., Arce, J.J., Nagata, Y., Nakamura, R.M., Thorneycroft, I.H. \& Mishell, D.R. (1973) Male pseudohermaphroditism due to testicular 17 $\beta$-hydroxysteroid dehydrogenase deficiency. J. clin. Endocr. Metab. 36, 867-879.
Lee, P.A., Rock, J.A., Brown, T.R., Migeon, C.J. \& Jones, H.W. (1982) Leydig cell hypofunction resulting in male pseudohermaphroditism. Fert. Steril. 37, $675-679$.

Lyon, M.F. \& Hawkes, S.G. (1970) X-linked gene for testicular feminization in the mouse. Nature, Lond. 227, 1217-1219.

Perez-Palacios, G., Scaglia, H.E., Kofman-Alfaro, S., Saavedra, O.D., Larraza, O. \& Perez, A.E. (1981) Inherited male pseudohermaphroditism due to gonadotrophin unresponsiveness. Acta endocr., Copenh. 98, 148-155.

Perez-Palacios, G., Ulla-Aguirre, A. \& Kofman-Alfaro, S. (1984) Inherited male pseudohermaphroditism: analogies between the human and rodent models. In Sexual Differentiation: Basic and Clinical Aspects, pp. 287-299. Eds M. Serio, M. Motta, M. Zanisi \& L. Martini. Raven Press, New York.

Peterson, R.E. \& Imperato-McGinley, J. (1984) Male pseudohermaphroditism due to inherited deficiencies of testosterone biosynthesis. In Sexual Differentiation: Basic and Clinical Aspects, pp. 301-319. Eds M. Serio, M. Motta, M. Zanisi \& L. Martini. Raven Press, New York.

Pfeiffer, C.A. (1936) Sexual differences of hypophyses and their determination by gonads. Am. J. Anat. 58, 195-225.

Schwartz, M., Imperato-McGinley, J., Peterson, R.E., Cooper, G., Morris, P.L., MacGillivray, M. \& Hensle, T. (1981) Male pseudohermaphroditism secondary to an abnormality in Leydig cell differentiation. J. clin. Endocr. Metab. 53, 123-127.

Stanley, A.J., Gumbreck, L.G., Allison, J.E. \& Easley, R.B. (1973) Male pseudohermaphroditism in the laboratory Norway rat. Recent Prog. Horm. Res. 29, 43-64.

Taya, K., Watanabe, G. \& Sasamoto, S. (1985) Radioimmunoassay for progesterone, testosterone and estradiol-17 $\beta$ using ${ }^{125} \mathrm{I}$ iodohistamine radioligands. Jpn. J. Anim. Reprod. 31, 186-197.

Wachtel, S.S., Ohno, S., Koo, G.C. \& Boyse, E.A. (1975) Possible role for H-Y antigen in the primary determination of sex. Nature, Lond. 257, 235-236.

Washburn, L.L. \& Eicher, E.M. (1983) Sex reversal in XY mice caused by dominant mutation on chromosome 17. Nature, Lond. 303, 338-340.

Yoshida, T.H. (1980) Cytogenetics of the Black Rat, pp. 222-230. University of Tokyo Press, Tokyo.

Received 9 February 1988 